\title{
CrimRxiv
}

\section{Triggered by defeat or victory? Assessing the impact of presidential election results on extreme right-wing mobilization online}

Ryan Scrivens, George W Burruss, Thomas J Holt, Steven M Chermak, Joshua D Freilich, Richard Frank

Published on: Jul 10, 2021

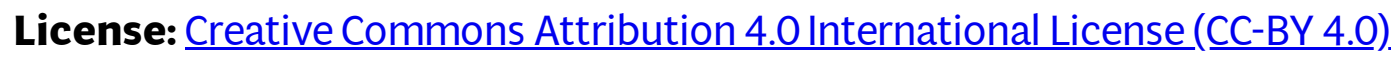


